\title{
Nitrogen digestion and metabolism in sheep consuming diets containing contrasting forms and levels of $\mathbf{N}$
}

\author{
By R. C. SIDDONS, J. V. NOLAN*, D. E. BEEVER AND J. C. MACRAE† \\ The Grassland Research Institute, Hurley, Maidenhead, Berkshire SL6 5LR
}

(Received 11 October 1984 - Accepted 22 February 1985)

\begin{abstract}
1. Nitrogen kinetics were studied in six sheep $(45-55 \mathrm{~kg}$ live weight) consuming either a high- $\mathrm{N}$ grass silage or a low- $\mathrm{N}$ dried grass made from swards of perennial ryegrass (Lolium perenne). The diets were fed hourly at a level of $600 \mathrm{~g}$ dry matter $/ \mathrm{d}$ and supplied 19.5 and $11.0 \mathrm{~g} \mathrm{~N} / \mathrm{d}$ respectively.

2. The amounts of organic matter (OM) consumed and flowing at the duodenum and ileum and excreted in the faeces were similar $(P>0.05)$ with both diets. Each diet supplied 23 g digestible $\mathrm{OM} / \mathrm{d}$ per $\mathrm{kg} \mathrm{live} \mathrm{weight}{ }^{0.75}$, which was sufficient to maintain body-weight.

3. There were no differences $(P>0.05)$ between diets in rumen fluid volume, fractional outflow rate of fluid from the rumen, total concentration of volatile fatty acids or molar proportion of acetate in the rumen. The $\mathrm{pH}$ and molar proportion of propionate in rumen fluid were higher $(P<0.01)$, and molar proportion of butyrate lower $(P<0.001)$ when the silage was given.

4. There was a net loss of $N(4.0 \mathrm{~g} / \mathrm{d})$ between mouth and duodenum when the silage was consumed but a net gain $(5.5 \mathrm{~g} / \mathrm{d})$ when the dried grass was consumed. As a result, total non-ammonia-N (NAN) flow at the duodenum did not differ $(P>0.05)$ between diets. Rumen microbial NAN flow at the duodenum, based on ${ }^{15} \mathrm{~N}$ as the marker, also did not differ $(P>0.05)$ between diets but the efficiency of microbial $\mathrm{N}$ synthesis in the rumen $(\mathrm{g} / \mathrm{kg}$ OM apparently digested) was higher $(P<0.05)$ with the dried grass.

5. When the sheep were consuming silage they had a higher concentration of ammonia in rumen fluid $(P<0.01)$, a higher rate of irreversible loss of ammonia from the rumen $(P<0.05)$ and a higher rate of absorption of ammonia across the rumen wall $(P<0.01)$. The rate of absorption was found to be more closely related to the unionized ammonia concentration in rumen fluid $\left(r^{2} 0 \cdot 85\right)$ than to the total ammonia concentration $\left(r^{2} 0 \cdot 36\right)$.

6. Endogenous $N$ entry into the forestomachs was calculated to be $5.5 \mathrm{~g} / \mathrm{d}$ when the silage was given and $9.4 \mathrm{~g} / \mathrm{d}$ when the dried grass was given, of which 1.7 and $3.5 \mathrm{~g} / \mathrm{d}$ respectively were in the form of urea. Thus, approximately 4-6 $\mathrm{g} \mathrm{N} / \mathrm{d}$ were derived from non-urea materials.

7. Within the small intestine the apparent absorption coefficient of rumen microbial NAN $(0 \cdot 72)$ did not differ $(P>0.05)$ between diets but the apparent absorption coefficient of total NAN was lower $(P<0.05)$ when the silage was given, owing to a lower $(P<0.01)$ absorption coefficient of the non-microbial NAN fraction (undegraded feed and endogenous).

8. Within the large intestine, diet had no effect $(P>0.05)$ on the apparent absorption coefficients of total $\mathrm{N}$ $(0 \cdot 22)$ and rumen microbial NAN $(0 \cdot 63)$.

9. Plasma urea concentration, the rate of urea synthesis in the body and urinary urea excretion were higher $(P<0.001)$ when the silage was consumed. However, the transfer of urea to the whole digestive tract and to the post-ruminal part of the tract did not differ $(P>0.05)$ between diets; urea transfer to the rumen was higher $(P<0.01)$ when the dried grass was given.

10. The results were used to construct a whole-animal model of $\mathbf{N}$ flows between the digestive tract and the tissues.
\end{abstract}

Current knowledge of nutrient supply to ruminant tissues has been greatly enhanced by the development of methods for sampling digesta via cannulas inserted at various sites in the digestive tract, and by the use of non-absorbable markers for measurement of the total flow of digesta (see Faichney, 1975; MacRae, 1975). Using these techniques it has been shown that the relation between nitrogen intake and protein flow into and absorption from the small intestine can vary markedly. For example, when high- $\mathbf{N}$ diets are fed there are generally net losses of $\mathrm{N}$ between mouth and duodenum, whereas the feeding of low- $\mathrm{N}$ diets is often associated with net gains of $\mathbf{N}$ across the forestomachs (Hogan \& Weston, 1970).

The nature of the dietary $\mathrm{N}$ constituents can also influence the relation between $\mathrm{N}$ intake and $\mathrm{N}$ flow to the small intestine. For example, when untreated silages containing highly

Present addresses: * Department of Biochemistry, Microbiology \& Nutrition, Armidale, NSW 2351, Australia. $\uparrow$ Rowett Research Institute, Bucksburn, Aberdeen AB2 9SB. 
soluble and therefore probably readily fermentable $\mathrm{N}$ constituents are consumed, a net loss of $\mathrm{N}$ between mouth and duodenum is generally observed. Artificial dehydration of grass, on the other hand, reduces $\mathrm{N}$ solubility and susceptibility to microbial fermentation and can give rise to duodenal $\mathrm{N}$ flows which exceed $\mathrm{N}$ intake (Beever, 1980), such effects being associated with increased amounts of undegraded dietary $\mathbf{N}$ flowing to the small intestine, often coupled with elevated flows of microbial $\mathbf{N}$.

Unfortunately, digesta flow measurements, whilst of obvious value, suffer the limitation that they describe only the net effects of processes occurring within a particular segment of the digestive tract and provide little information about underlying mechanisms. However, if made in conjunction with isotope tracer experiments which enable exchanges between metabolites to be estimated along with transfers by absorption or endogenous entry, then a more complete understanding of the digestive and metabolic processes can be obtained. Such techniques were applied in the present study in order to obtain quantitative information on $\mathrm{N}$ kinetics in sheep receiving two diets, i.e. a high- $\mathrm{N}$ grass silage and a low-N dried grass which supplied the same amount of digestible organic matter (OM) but differed markedly in the amount and nature of the $\mathrm{N}$ constituents supplied.

\section{EXPER I MENT A L}

\section{Animals and diets}

Six mature Suffolk $\times$ Halfbred wethers $(45-55 \mathrm{~kg}$ live weight) each fitted with a simple cannula into the dorsal sac of the rumen and re-entrant cannulas into the proximal duodenum and terminal ileum, were used. They were kept in metabolism cages whilst on experiment and in resting pens between periods. The two diets consisted of either a high-N grass silage or a low- $\mathrm{N}$ dried grass. They were prepared from different swards of primary growth perennial ryegrass (Lolium perenne cv. S23). The harvested grass from one sward was ensiled directly without additive treatment, whilst the grass from the other sward was artificially dried in a high-temperature rotary drum drier and cobbed. Full details of the preparation of the silage and dried grass have been given previously (Siddons et al. 1982b). The daily allocation of each diet ( $600 \mathrm{~g}$ dry matter (DM)) was given in twenty-four equal hourly portions using automatic feeders. No drinking-water was supplied but, instead, tap-water was infused continuously into the rumen at a rate of $20 \mathrm{ml} / \mathrm{h}$ when the silage was given and $40 \mathrm{ml} / \mathrm{h}$ when dried grass was given.

\section{Experimental procedure}

The experiment consisted of two periods each of 7-weeks duration with at least 3 weeks adaptation to diet before each period commenced. In period 1 all sheep were given the silage and in period 2 the dried grass. Representative samples of the two feeds were taken at regular intervals throughout each period and bulked for subsequent analysis. The sheep were weighed at the beginning and end of each period. The results given in the present paper relate to measurements made during the first 4 weeks of each period, whilst the experimental procedures performed in the latter part of each period are relevant to an associated study which will be reported separately. During the first $4 \mathrm{~d}$ of each period, 'donor' duodenal and ileal digesta were collected from all sheep and stored at $-15^{\circ}$ until used to replace digesta removed during the appropriate digesta collection periods. Digesta samples were also taken during the first $4 \mathrm{~d}$ for estimating background levels of the isotopes. On day 6 , $\mathrm{NaH}^{14} \mathrm{CO}_{3}$ was continuously infused $(58 \mathrm{kBq} / \mathrm{h})$ into the rumen for $21 \mathrm{~h}$ and the specific radioactivity of rumen bicarbonate and of plasma urea-carbon were determined in rumen liquor and blood samples taken at hourly intervals during the last $6 \mathrm{~h}$ of the infusion. During 
days 11-20, the total daily output of faeces and urine (into $20 \mathrm{ml} 5 \mathrm{M}$-sulphuric acid) were collected. At the beginning of the faecal collection period, a priming dose of ruthenium phenanthroline (Ru-P) was administered into the rumen and the infusion of tap-water replaced by a continuous intraruminal infusion of $\mathrm{Ru}-\mathrm{P}(7.2 \mathrm{mg} \mathrm{Ru} / \mathrm{d})$ which was maintained for $6 \mathrm{~d}$. During the last $2 \mathrm{~d}$ of the Ru-P infusion, $\mathrm{Na}_{2}{ }^{35} \mathrm{SO}_{4}(7 \cdot 4 \mathrm{MBq} / \mathrm{d})$ was also included in the infusion solution, and $\left({ }^{15} \mathrm{NH}_{4}\right)_{2} \mathrm{SO}_{4}\left(96\right.$ atoms ${ }^{15} \mathrm{~N} / 100$ atoms $\mathrm{N}, 3.54 \mathrm{mg}$ atoms ${ }^{15} \mathrm{~N} / \mathrm{d}$ ) was continuously infused into the rumen via a separate infusion line. The data derived with ${ }^{35} \mathrm{~S}$ were reported by Siddons et al. $(1982 b)$ and are not considered in the present paper. Four samples of rumen fluid, three samples of rumen microbes and four samples of blood were taken during the last $12 \mathrm{~h}$ of the $\left({ }^{15} \mathrm{NH}_{4}\right)_{2} \mathrm{SO}_{4}$ infusion. A representative sample of total duodenal digesta flow was also collected, using an automatic sampling machine, during the last $12 \mathrm{~h}$ of the infusion. In addition, representative samples of total ileal digesta flow and faeces excreted during the last $10 \mathrm{~h}$ of the infusion were obtained by manual collection. On day 24 , each sheep was given an intravenous injection of $\left[{ }^{14} \mathrm{C}\right]$ rea $(2.59 \mathrm{MBq}, 50 \mathrm{mg})$ in $10 \mathrm{ml}$ saline $(9 \mathrm{mg}$ sodium chloride/l) and the changes in the specific radioactivity of plasma urea and rumen bicarbonate-carbon were followed over a period of $27 \mathrm{~h}$ : rumen samples were taken at $0,10,40,70,90,120,200,300,500,1400$ and $1600 \mathrm{~min}$ and blood samples taken at $0,15,25,60,100,200,300,500,700,1400$ and $1600 \mathrm{~min}$ after the injection. On day 26, a single intraruminal dose of CrEDTA (200 mg Cr) w:s given and rumen fluid samples taken at $0,60,80,100,200,300,500,700,1200$ and $1400 \mathrm{~min}$ after the dose was given.

\section{Sample preparation}

Acidified urine samples were stored at $-15^{\circ}$. Faeces, duodenal digesta and ileal digesta were freeze-dried, ground and stored at $-15^{\circ}$. Rumen fluid samples were acidified $(\mathrm{pH}<3)$ with $5 \mathrm{M}-\mathrm{H}_{2} \mathrm{SO}_{4}$ and stored at $-15^{\circ}$. Rumen microbial fractions were prepared by differential centrifugation of unacidified rumen fluid as described by Siddons et al. (1982b) and stored at $-15^{\circ}$. Blood samples were collected in heparinized tubes, then centrifuged at $3000 \mathrm{~g}$ for $10 \mathrm{~min}$ and the plasma stored at $-15^{\circ}$.

\section{Analytical methods}

The methods used for determining the DM, OM, N and ammonia contents of the feeds, duodenal and ileal digesta, microbial samples, faeces and urine, as well as the Ru content of digesta and infusion solutions, have been described by Siddons et al. $(1982 b)$. The buffer-soluble $\mathrm{N}$ content of the feeds was determined as described by Siddons et al. (1982a). The $\mathrm{Cr}$ content of rumen fluid samples and infusion solutions was determined by atomic absorption spectrophotometry and the volatile fatty acid (VFA) concentrations in rumen fluid samples by gas chromatography (Beever et al. 1978). The methods used for measuring enrichment with ${ }^{15} \mathrm{~N}$ and ${ }^{14} \mathrm{C}$ specific radioactivity have been described by Nolan \& Leng (1972), Kempton et al. (1979) and Nolan \& Stachiw (1979).

\section{Calculations}

The flows of digesta constituents at the duodenum and ileum were calculated by reference to $\mathrm{Ru}$, as described by Siddons et al. (1982b). The ${ }^{15} \mathrm{~N}$ enrichment ratio of digesta or faecal NAN and of the $\mathbf{N}$ of the microbial fraction isolated from rumen fluid was used to calculate rumen microbial NAN flow at the duodenum and ileum and excretion in faeces. This assumes that all ${ }^{15} \mathrm{~N}-\mathrm{NAN}$ reaching the duodenum and ileum and excreted in faeces was of rumen microbial origin. Appropriate corrections were made to allow for the replacement of labelled digesta by unlabelled digesta during the collections. Irreversible loss rates and transfer quotients (i.e. the proportion of $\mathrm{N}$ or $\mathrm{C}$ in a secondary pool derived from the 
primary pool) were estimated as described by Nolan \& Leng (1974) and Nolan et al. (1976). Ammonia apparently absorbed from the reticulo-rumen was estimated from the intraruminal infusion of $\left({ }^{15} \mathrm{NH}_{4}\right)_{2} \mathrm{SO}_{4}$ as follows:

Ammonia absorption $(\mathrm{g} \mathrm{N} / \mathrm{d})=$

$\frac{\left.{ }^{15} \mathrm{~N} \text { not recovered at the outflow point ( } \mathrm{g} \text { atoms } \mathrm{N} / \mathrm{d}\right)}{\text { rumen ammonia enrichment }\left(\mathrm{g} \text { atoms }{ }^{15} \mathrm{~N} / \mathrm{g} \text { atoms } \mathrm{N}\right)} \times 14$.

where outflow of ${ }^{15} \mathrm{~N}$ was calculated as the sum of the flows of $\left[{ }^{15} \mathrm{~N}\right]$ ammonia in fluid passing out of the reticulo-rumen (litres/d $\times \mathrm{g}$ atoms $\left.\left[{ }^{15} \mathrm{~N}\right] a m m o n i a / 1\right)$ and the flow into the small intestine of ${ }^{15} \mathrm{~N}-\mathrm{NAN}$ in whole digesta $\left(\mathrm{g} / \mathrm{d} \times \mathrm{g}\right.$ atoms $\left.{ }^{15} \mathrm{~N}-\mathrm{NAN} / \mathrm{g}\right)$; whilst the total $\left[{ }^{15} \mathrm{~N}\right] \mathrm{ammonia}$ entering the reticulo-rumen was taken to be that infused plus that in endogenous urea (the product of urea transfer and enrichment). The concentration of un-ionized ammonia $\left(\mathrm{NH}_{3}\right)$ in rumen fluid was calculated from the measured $\mathrm{pH}$ and total ammonia $\left(\mathrm{NH}_{3}\right.$ and $\left.\mathrm{NH}_{4}{ }^{+}\right)$concentration, according to the Henderson-Hasselbach equation, and assuming a $p K_{a}$ of 9.0 (Visek, 1968). The flow of $\mathrm{C}$ between plasma urea and rumen bicarbonate was estimated using a two-pool model (Nolan et al. 1976). Rumen fluid volume and outflow rate from the rumen was estimated from the decrease in the $\mathrm{Cr}$ concentration of rumen fluid after the single intraruminal injection of CrEDTA (Warner \& Stacy, 1968).

\section{Statistical methods}

Diet and time were confounded but, because mature sheep were used, the effect of time was likely to be negligible. The dietary adaptation period was also likely to minimize any carry-over effects. Analysis of variance was used to compare results for the six sheep for each diet. In order to establish whether results from animals on both diets could be combined for regression analysis, covariance analysis (Snedecor $\&$ Cochran, 1967) was used.

\section{RESULTS}

The DM contents of the silage and the dried grass were 217 and $895 \mathrm{~g} / \mathrm{kg}$ fresh weight respectively. The total $\mathrm{N}$ content of the silage was considerably higher than that of the dried grass $(32 \cdot 1 v .18 \cdot 3 \mathrm{~g} / \mathrm{kg} \mathrm{DM})$ as was the ammonia $\mathrm{N}$ content $(3.5 v .0 .2 \mathrm{~g} / \mathrm{kg} \mathrm{DM})$ and the buffer-soluble $\mathrm{N}$ content ( $23.8 v .3 .7 \mathrm{~g} / \mathrm{kg} \mathrm{DM})$.

Results for rumen measurements when the sheep were consuming the two diets are given in Table 1. Rumen fluid volume, fractional rate of outflow of fluid, total VFA concentration and molar proportion of acetate did not differ $(P>0.05)$ between diets. Rumen ammonia concentration (see Table 4, p. 181), $\mathrm{pH}$ and molar proportion of propionate were all higher $(P<0.01)$ when the silage was given, whilst the molar proportion of butyrate was lower $(P<0.001)$.

The amounts of $\mathrm{OM}$ and $\mathrm{N}$ consumed and passing through the different parts of the digestive tract are given in Table 2. OM intake was similar for both diets and amounts flowing through the duodenum and ileum and excreted in the faeces did not differ $(P>0.05)$ between diets. Total N and NAN intakes were higher when the silage was given but because there was a net loss of $\mathrm{N}$ in the forestomachs with the silage and a net gain with the dried grass, the flows of total N and total NAN at the duodenum did not differ $(P>0.05)$ between diets. There was also no difference $(P>0.05)$ between diets in total $\mathrm{N}$ flow at the ileum or excretion in the faeces, whereas total NAN flow at the ileum was higher $(P<0.05)$ with the silage. In contrast, rumen microbial NAN flow at the ileum was higher $(P<0.05)$ when the dried grass was given, although amounts flowing at the duodenum and excreted in faeces did not differ $(P>0.05)$ between diets. The flow of non-microbial NAN at the duodenum was similar $(P>0.05)$ with both diets, whereas flow at the ileum was higher $(P<0.05)$ with 
Table 1. Rumen indices in sheep given grass silage or dried grass

(Mean values for six sheep per diet)

\begin{tabular}{|c|c|c|c|c|}
\hline & Silage & $\begin{array}{l}\text { Dried } \\
\text { grass }\end{array}$ & SEM & $\begin{array}{c}\text { Statistical } \\
\text { significance } \\
\text { of difference }\end{array}$ \\
\hline Fluid volume (litres) & 4.7 & $5 \cdot 1$ & $0 \cdot 40$ & NS \\
\hline $\begin{array}{l}\text { Fluid fractional } \\
\text { outflow rate }(/ d)\end{array}$ & 1.8 & $1 \cdot 8$ & 0.19 & NS \\
\hline $\mathrm{pH}$ & $7 \cdot 0$ & 6.3 & $0 \cdot 10$ & ** \\
\hline Total VFA (mmol/l) & 639 & 742 & 33.8 & NS \\
\hline \multicolumn{5}{|l|}{ VFA molar proportions } \\
\hline Acetate & 0.68 & 0.69 & 0.003 & NS \\
\hline Propionate & 0.24 & 0.21 & 0.005 & $* *$ \\
\hline Butyrate & 0.08 & $0 \cdot 10$ & 0.003 & *** \\
\hline
\end{tabular}

VFA, volatile fatty acids; NS, not significant $(P>0.05)$.

${ }^{* *} P<0.01,{ }^{* * *} P<0.001$.

Table 2. Intake and flow $(\mathrm{g} / \mathrm{d})$ of digesta constituents through the digestive tract, and urinary total nitrogen excretion and $N$ retention in sheep given grass silage or dried grass

(Mean values for six sheep per diet)

\begin{tabular}{|c|c|c|c|c|}
\hline & Silage & $\begin{array}{c}\text { Dried } \\
\text { grass }\end{array}$ & SEM & $\begin{array}{c}\text { Statistical } \\
\text { significance } \\
\text { of difference }\end{array}$ \\
\hline \multicolumn{5}{|l|}{ Organic matter } \\
\hline Intake & 563 & 566 & & \\
\hline At duodenum & 240 & 271 & $11 \cdot 2$ & NS \\
\hline At ileum & 154 & 150 & $3 \cdot 7$ & NS \\
\hline In faeces & 126 & 124 & $5 \cdot 7$ & NS \\
\hline \multicolumn{5}{|l|}{ Total N } \\
\hline Intake & $19 \cdot 5$ & $11 \cdot 0$ & & \\
\hline At duodenum & $15 \cdot 5$ & 16.5 & 0.72 & NS \\
\hline At ileum & 6.8 & $5 \cdot 4$ & 0.41 & NS \\
\hline In faeces & $4 \cdot 7$ & $4 \cdot 2$ & 0.18 & NS \\
\hline In urine & $13 \cdot 2$ & $6 \cdot 7$ & 0.43 & *** \\
\hline Retention in the body & $1 \cdot 6$ & $0 \cdot 2$ & 0.60 & NS \\
\hline \multicolumn{5}{|l|}{$\begin{array}{l}\text { Total non-ammonia-N } \\
\text { (NAN) }\end{array}$} \\
\hline Intake & $17 \cdot 3$ & $10 \cdot 9$ & & \\
\hline At duodenum & $14 \cdot 0$ & $15 \cdot 5$ & 0.63 & NS \\
\hline At ileum & 6.7 & $5 \cdot 3$ & 0.39 & $*$ \\
\hline \multicolumn{5}{|l|}{ Rumen microbial NAN } \\
\hline At duodenum & 6.9 & $7 \cdot 7$ & 0.29 & NS \\
\hline At ileum & 1.8 & $2 \cdot 4$ & $0 \cdot 11$ & * \\
\hline In faeces & 0.6 & $1 \cdot 0$ & $0 \cdot 14$ & NS \\
\hline \multicolumn{5}{|l|}{ Non-microbial NAN } \\
\hline At duodenum & $7 \cdot 1$ & $7 \cdot 8$ & 0.72 & NS \\
\hline At ileum & 4.8 & 2.9 & 0.48 & * \\
\hline
\end{tabular}

NS, not significant $(P>0.05)$.

${ }^{*} P<0.05,{ }^{* * *} P<0.001$. 
Table 3. Apparent absorption coefficients for nitrogen and various non-ammonia-N (NAN) fractions in the digestive tract of sheep given grass silage or dried grass

(Mean values for six sheep per diet)

\begin{tabular}{lcccc}
\hline \hline & Silage & $\begin{array}{c}\text { Dried } \\
\text { grass }\end{array}$ & SEM & $\begin{array}{c}\text { Statistical } \\
\text { significance } \\
\text { of difference }\end{array}$ \\
\hline$\quad \begin{array}{llll}\text { Whole digestive tract } \\
\quad \text { Total N }\end{array}$ & 0.76 & 0.62 & 0.022 & $* *$ \\
$\quad$ Small intestine & & & & \\
$\quad$ Total N & 0.56 & 0.67 & 0.021 & $*$ \\
$\quad$ Total NAN & 0.52 & 0.66 & 0.027 & $*$ \\
$\quad$ Microbial NAN & 0.73 & 0.69 & 0.015 & NS \\
$\quad$ Non-microbial NAN & 0.31 & 0.62 & 0.054 & $*$ \\
$\quad$ Large intestine & & & & \\
$\quad$ Total N & 0.23 & 0.20 & 0.07 & NS \\
$\quad$ Rumen microbial NAN & 0.66 & 0.60 & 0.05 & NS \\
\hline \hline
\end{tabular}

NS, not significant $(P>0 \cdot 05)$.

* $P<0.05$, ** $P<0.01$.

the silage. Urinary $\mathrm{N}$ excretion was higher $(P<0.001)$ when the silage was consumed and $\mathrm{N}$ retention also tended to be higher, but the difference was not significant $(P>0.05)$.

Apparent absorption coefficients for the various $\mathrm{N}$ fractions are given in Table 3 . The apparent absorption coefficient of total $\mathrm{N}$ in the whole digestive tract was higher $(P<0.01)$ when the silage was given, mainly as a result of the large net loss of $\mathrm{N}$ before the small intestine. Within the small intestine the apparent absorption coefficients of total $\mathrm{N}$ $(P<0.05)$, total NAN $(P<0.05)$ and non-microbial NAN $(P<0.01)$ were lower with the silage diet. However, the apparent absorption coefficient of rumen microbial NAN in the small intestine did not differ $(P>0.05)$ between diets and, with both diets, was higher than that of total NAN. Similarly, in the large intestine the apparent absorption coefficient of rumen microbial NAN was considerably higher than for total $\mathrm{N}$. Both total $\mathrm{N}$ and rumen microbial NAN absorption coefficients in the large intestine did not differ $(P>0.05)$ between diets.

Results for rumen ammonia and plasma urea kinetics are given in Table 4. Ammonia concentration in rumen fluid $(P<0.01)$, the rate of irreversible loss of ammonia from the rumen fluid pool $(P<0.05)$, ammonia outflow in rumen fluid $(P<0.05)$ and the apparent absorption of ammonia from the rumen $(P<0.01)$ were higher with the silage diet. The minimum total flux of ammonia, which includes ammonia recycled via plasma urea but excludes intra-ruminal recycling (e.g. via microbial $\mathrm{N}$ pools) also tended to be higher when silage was given, but the difference was not significant $(P>0.05)$. Neither the proportion of rumen microbial $\mathrm{N}$ arising from rumen ammonia nor the net incorporation of ammonia by the rumen microbes differed significantly $(P>0.05)$ between diets, although both tended to be lower when silage was given. The proportion of duodenal ammonia $\mathrm{N}$ arising directly from rumen ammonia was very similar $(P>0.05)$ with both diets.

Plasma urea concentration, the rate of irreversible loss of urea in the body and urea excretion in urine were all considerably higher $(P<0.001)$ when the silage was consumed. However, there was no difference $(P>0.05)$ between diets in the amount of urea transferred either to the whole of the digestive tract or to the post-ruminal part of the tract but transfer to the rumen was higher $(P<0.01)$ when the dried grass was consumed. 
Table 4. Rumen ammonia and plasma urea kinetics ( $g$ nitrogen/d) in sheep given grass silage or dried grass

(Mean values for six sheep per diet)

\begin{tabular}{|c|c|c|c|c|}
\hline & Silage & $\begin{array}{l}\text { Dried } \\
\text { grass }\end{array}$ & SEM & $\begin{array}{c}\text { Statistical } \\
\text { significance } \\
\text { of difference }\end{array}$ \\
\hline \multicolumn{5}{|l|}{ Rumen ammonia } \\
\hline \multicolumn{5}{|l|}{ Total concentration } \\
\hline$(\mathrm{mg} \mathrm{N} / \mathrm{l})$ & 144 & 75 & 11.9 & *** \\
\hline Irreversible loss & $14 \cdot 3$ & $9 \cdot 3$ & $1 \cdot 24$ & * \\
\hline Outflow in fluid & $1 \cdot 1$ & 0.7 & 0.06 & * \\
\hline Apparent absorption & $9 \cdot 5$ & 3.9 & 0.96 & ** \\
\hline Net microbial incorporation & $4 \cdot 5$ & $6 \cdot 1$ & 0.48 & NS \\
\hline Minimum total flux $\dagger$ & $15 \cdot 1$ & $10 \cdot 7$ & $1 \cdot 37$ & NS \\
\hline Proportion of microbial N & 0.65 & 0.80 & 0.050 & NS \\
\hline $\begin{array}{l}\text { Proportion of duodenal } \\
\text { ammonia-N }\end{array}$ & 0.46 & 0.42 & 0.046 & NS \\
\hline \multicolumn{5}{|l|}{ Plasma urea } \\
\hline \multicolumn{5}{|l|}{ Total concentration } \\
\hline Irreversible loss & $16 \cdot 6$ & $11 \cdot 3$ & 0.25 & $* * *$ \\
\hline Excretion in urine & $10 \cdot 3$ & 3.4 & $0 \cdot 21$ & *** \\
\hline \multicolumn{5}{|l|}{ Transfer to } \\
\hline Digestive tract & $6 \cdot 3$ & 7.9 & 0.79 & NS \\
\hline Rumen & 1.7 & $3 \cdot 5$ & $0 \cdot 24$ & $* *$ \\
\hline Lower tract & $4 \cdot 6$ & $4 \cdot 3$ & 0.56 & NS \\
\hline
\end{tabular}

NS, not significant $(P>0.05)$.

* $P<0.05,{ }^{* *} P<0.01,{ }^{* * *} P<0.001$.

$\dagger$ Includes ammonia- $\mathbf{N}$ recycled via plasma urea.

\section{DISCUSSION}

The two forage rations used were known to contain markedly different forms and quantities of nitrogenous material but similar amounts of digestible $\mathrm{OM}$ and therefore were comparable in relation to energy but contrasting in relation to $\mathrm{N}$ supply. The intake of digestible organic matter (DOM) was $23 \mathrm{~g} / \mathrm{d}$ per kg live weight $\mathrm{t}^{0 \cdot 75}$ and was found to be sufficient to maintain live weight $( \pm 1 \mathrm{~kg})$ throughout the study. The pattern of $O M$ digestion was generally similar for the two diets, although with the silage diet more of the DOM disappeared anterior to the small intestine $(0.74 v .0 .67)$ and slightly less in the small intestine $(0.20$ v. 0.27$)$. There were differences between the diets in the fermentation processes occurring in the rumen as evidenced by a higher rumen $\mathrm{pH}$, rumen ammonia concentration and molar proportion of propionate and a lower molar proportion of butyrate when the silage was consumed, presumably reflecting differences in the nature of the OM fermented and possibly differences in the predominant microbial populations present. The intakes of total $\mathrm{N}(19.5 \mathrm{v} .11 .0 \mathrm{~g} / \mathrm{d})$ and soluble $\mathrm{N}$, and therefore probably readily-fermentable $N(14 \cdot 4 v \cdot 2 \cdot 2 \mathrm{~g} / \mathrm{d})$ differed considerably between diets and resulted in marked differences in $\mathbf{N}$ digestion and metabolism.

\section{Feed $N$ degradability}

There was a net loss of $\mathrm{N}$ across the forestomachs of $4.0 \mathrm{~g} / \mathrm{d}$ when the silage was consumed, compared with a net gain of $5.5 \mathrm{~g} / \mathrm{d}$ when dried grass was consumed, which would tend 


\section{R. C. Siddons, J. V. Nolan, D. E. Beever and J. C. MacRae}

to suggest that considerably more of the silage $\mathbf{N}$ was degraded in the rumen. However, precise estimation of the extent to which the $\mathrm{N}$ in the diets was degraded is confounded by the unknown endogenous contribution to duodenal NAN flow. Total N and NAN flows at the duodenum were similar with the two diets and with both diets approximately half the NAN was microbial in origin. If, as has been suggested (Agricultural Research Council, 1980 ), all the non-microbial $N$ reaching the duodenum is considered to be undegraded feed $\mathrm{N}$, then 0.56 and 0.20 of the silage and dried grass $\mathrm{N}$ respectively were degraded in the forestomachs. This makes no allowance for endogenous $\mathbf{N}$ in duodenal digesta, although Harrop (1974) found abomasal organic $N$ secretion in sheep to range from 0.5 to $2.6 \mathrm{~g} / \mathrm{d}$. Assuming a mean duodenal flow of $1.5 \mathrm{~g}$ endogenous NAN/d, then $5.6 \mathrm{~g} / \mathrm{d}$ and $6.3 \mathrm{~g} / \mathrm{d}$ of silage and dried grass $\mathrm{NAN}$ respectively, flowed at the duodenum, giving $\mathrm{N}$ degradability values of 0.71 and 0.43 respectively. However, in addition to abomasal secretions, endogenous $\mathbf{N}$ is also added to digesta in the reticulo-rumen and the omasum. Under steady-state conditions total $\mathrm{N}$ inputs to the forestomachs (dietary and endogenous) must balance $\mathrm{N}$ losses (absorption and outflow). Thus, from a knowledge of dietary $\mathrm{N}$ intake and the estimated losses by absorption and $\mathrm{N}$ flow to the duodenum, it can be calculated that at least $5.5 \mathrm{~g}$ and $9.4 \mathrm{~g}$ of endogenous $\mathrm{N} / \mathrm{d}$ must have entered the forestomachs when the sheep were given the silage and dried grass respectively, of which 1.7 and $3.5 \mathrm{~g} / \mathrm{d}$ respectively were in the form of urea. Thus, endogenous non-urea $N$ entering the forestomachs amounted to 3.8 and $5.9 \mathrm{~g} / \mathrm{d}$ respectively. Some of this non-urea-N may enter as muco-proteins in saliva and as keratinized protein in cells sloughed from the rumen wall. The extent of fermentation of these forms of $\mathrm{N}$ in the rumen is not known but if low could markedly affect estimates of feed $\mathrm{N}$ degradability. For example, in the unlikely event that all of the endogenous non-urea- $N$ entering the forestomachs passed undegraded to the duodenum, the estimated $\mathrm{N}$ degradability would be 0.83 for both the silage and the dried grass.

\section{Microbial $N$ synthesis}

Microbial $\mathbf{N}$ flow to the duodenum tended to be higher when dried grass was consumed, while the amount of OM apparently disappearing in the rumen (OMADR) tended to be lower. Consequently, the efficiency of microbial $\mathrm{N}$ synthesis in the rumen was higher $(P<0.05)$ with the dried grass $(26 \mathrm{~g} \mathrm{~N} / \mathrm{kg}$ OMADR $)$ than with the silage diet $(21 \mathrm{~g} \mathrm{~N} / \mathrm{kg}$ OMADR). A lower efficiency of microbial $\mathrm{N}$ synthesis in the rumen when untreated silages are fed has been observed in other studies (Thomas et al. 1980) and may, at least in part, reflect a reduced yield of ATP during the fermentation of organic acids and degradable nitrogenous compounds present in the silage. The proportion of the microbial $\mathbf{N}$ derived from the rumen ammonia pool also tended to be lower with the silage diet even though the rumen ammonia concentration was considerably higher. However, with both diets rumen ammonia concentration was higher than that $(3 \mathrm{mmol} / \mathrm{l})$ generally considered adequate to meet microbial requirements (Satter \& Slyter, 1974).

\section{Rumen ammonia and urea kinetics}

When the sheep consumed the silage, the rate of irreversible loss and minimum total flux of ammonia in the rumen were higher than when they consumed the dried grass, reflecting the higher intake of readily fermentable $\mathrm{N}$ in the silage. The estimated minimum total flux was higher than the irreversible loss rate because it takes account of ${ }^{15} \mathrm{~N}$ recycled via plasma urea, although the actual total flux is likely to be still higher as all recycling of ${ }^{15} \mathrm{~N}$ external to the rumen will not have been accounted for (Nolan, 1975). Recycling within the rumen through the pathway: ammonia $\rightarrow$ microbes $\rightarrow$ ammonia is also not included and in some cases may represent as much as 0.5 of the irreversible loss rate of ammonia (Nolan \& Stachiw, 1979). Loss of ammonia from the rumen occurs by outflow, either as ammonia 


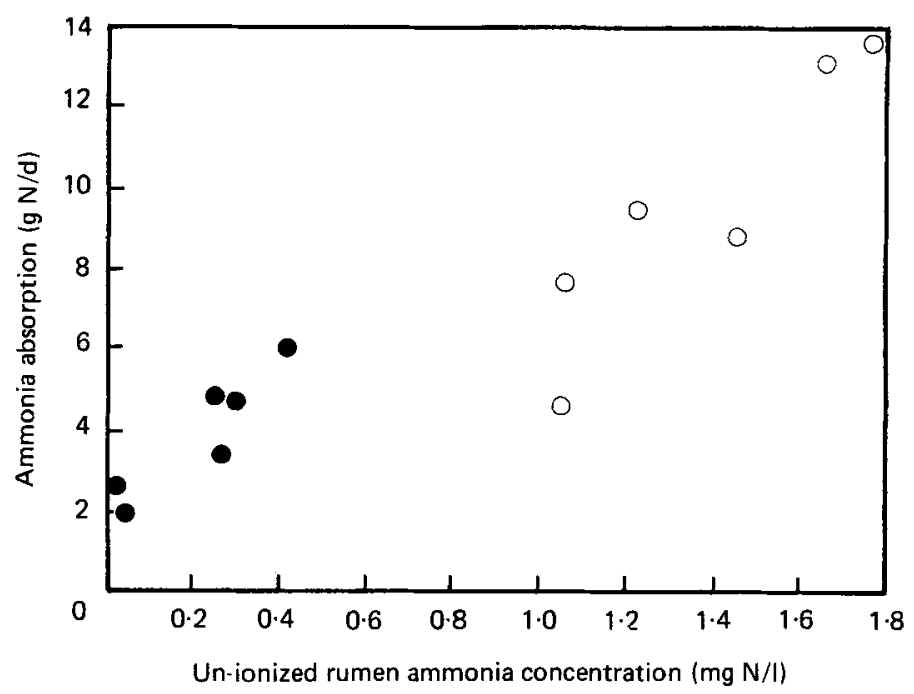

Fig. 1. The relation between the rate of ammonia absorption from the reticulo-rumen (g nitrogen/d) and the concentration of un-ionized $\mathrm{NH}_{3}$ in rumen fluid $(\mathrm{mg} \mathrm{N} / \mathrm{l})$ in sheep given silage $(\mathrm{O})$ or dried grass (O).

$$
y=2 \cdot 29+5 \cdot 54 x\left(\text { RSD } 1 \cdot 556, r^{2} 0 \cdot 85\right) \text {. }
$$

per se or after incorporation into microbial $\mathrm{N}$, and by absorption. With both diets, ammonia outflow per se accounted for 0.05 of irreversible loss and in absolute terms was higher with the silage diet. Ammonia outflow as microbial $\mathrm{N}$ tended to be higher with the dried grass diet, due partly to a tendency for net microbial $\mathrm{N}$ outflow to be higher and partly to a tendency for a greater proportion of the microbial $\mathrm{N}$ to be derived from the rumen ammonia pool. Ammonia absorption from the rumen amounted to 0.66 of ammonia irreversible loss with the silage diet compared with 0.42 of ammonia irreversible loss with the dried grass diet, representing a difference of $5.6 \mathrm{~g} \mathrm{~N} / \mathrm{d}$.

Despite hourly feeding, and the maintenance of constant intraruminal infusions of ${ }^{15} \mathrm{~N}$, the rumen ammonia plateau enrichment values in samples obtained from individual sheep showed considerable variation (coefficient of variation $0.08-0.40$ ) in contrast with the smaller variation (coefficient of variation $0.05-0 \cdot 10$ ) for rumen microbial $\mathrm{N}$ plateau enrichment values. The variability associated with the rumen ammonia pool is probably a function of its relatively small size $(0.4-0.7 \mathrm{~g} \mathrm{~N})$ and rapid turnover $(22-26 / \mathrm{d})$ whereas the rumen microbial pool is much larger and turns over more slowly $(<3 / \mathrm{d})$ (Hungate, 1966). As well as variations between samples obtained from individual sheep, there was also considerable variation in the mean rumen ammonia enrichment of sheep given the same diet and, consequently, in estimates of minimum ammonia flux in the rumen and ammonia absorption from the rumen. Using individual results from animals consuming both diets a linear relation between ammonia absorption and total ammonia concentration $(P<0.01$, $r^{2}$ 0.36) was found, which suggests that ammonia transference across the rumen wall is effected by simple diffusion (Lewis et al. 1957). However, when the concentration of un-ionized ammonia $\left(\mathrm{NH}_{3}\right)$ was calculated according to the Henderson-Hasselbach equation, from total rumen ammonia $\left(\mathrm{NH}_{3}\right.$ and $\mathrm{NH}_{4}^{+}$) concentration and rumen $\mathrm{pH}$, and related to ammonia absorption, considerably more of the variation was accounted for $\left(P<0.001, r^{2} 0.85\right)$ (Fig. 1). The improvement in the relations is consistent with the suggestion (Hogan, 1961) that $\mathrm{NH}_{3}$ diffuses through the rumen wall more freely than $\mathrm{NH}_{4}^{+}$. From closer examination of Fig. 1, the possibility of distinct relations for the two diets 
cannot be ignored, but when tested, the slopes of the relations within diets did not differ $(P>0 \cdot 05)$ significantly.

Accepting the relations presented in Fig. 1, it follows that a small change in rumen $\mathrm{pH}$, through its effect on un-ionized ammonia concentration, can have a marked effect on ammonia absorption from the rumen. The significant intercept suggests that ammonia absorption from the rumen would still occur when rumen un-ionized $\mathrm{NH}_{3}$ was zero. One explanation for this is that the measured flow of ${ }^{15} \mathrm{~N}-\mathrm{NAN}$ at the duodenum, which is used in the calculation of ammonia absorption (see p. 178), underestimates that flowing from the rumen through the reticulo-rumen orifice (e.g. because microbial $\mathrm{N}$ may be degraded in the omasum). In this event, the intercept may represent ammonia (or amino acid) absorption from the omasum. Alternatively, a small but significant amount of ionized $\mathrm{NH}_{4}^{+}$ may cross the rumen wall, and continue to do so when $\mathrm{NH}_{3}$ concentration approaches zero. A third possibility is that the concentration of $\mathrm{NH}_{3}$ at the rumen wall may differ from that in samples of rumen fluid.

The rate of endogenous transfer of urea to the rumen was higher when the sheep consumed the dried grass than when they consumed the silage. This is in agreement with other studies (e.g. Kennedy \& Milligan, 1980) which have shown the rate of urea transfer to the rumen to increase as rumen ammonia concentration decreased. On the other hand, these workers also found urea transfer to the rumen to increase as plasma urea concentration increased, whereas, in the present study, higher rates of transfer occurred in the dried grass when plasma urea concentration was only 0.40 of that on the silage diet. However, other factors such as an enhanced salivary secretion rate, or the presence of higher $(P<0.05)$ levels of butyrate in the rumen (Norton et al. 1982) may have contributed to the higher urea transfer with the dried-grass diet.

\section{$N$ digestion in the small intestine}

With both diets, less than half $(0.42$ and 0.46$)$ of the ammonia entering the duodenum arose directly from the rumen ammonia pool. Thus unlabelled ammonia of at least an equivalent quantity to that leaving the rumen must have been added in the omasum or abomasum. However, the flow of ammonia into the duodenum was not double that leaving the rumen indicating that ammonia absorption $(0.9 \mathrm{~g} / \mathrm{d}$ with the silage and $0.7 \mathrm{~g} / \mathrm{d}$ with the dried grass) occurred between the rumen and duodenum and probably from the omasum (Engelhardt \& Hauffe, 1975). Ammonia that entered the small intestine was mostly absorbed before the digesta reached the ileum (Table 2).

Total NAN flow into the small intestine did not differ $(P>0.05)$ between diets but its apparent absorption coefficient in, and therefore net absorption from, the small intestine was higher when dried grass was consumed. This was not due to a difference in the apparent absorption coefficient of the rumen microbial NAN reaching the small intestine but to the higher absorption coefficient of the non-microbial NAN of dietary and endogenous origin when dried grass was consumed. It would therefore appear that forage protein which is resistant to the degradative processes both during ensiling and within the rumen may also be resistant to enzymic digestion in the small intestine.

The flows of rumen microbial NAN at the duodenum, ileum and excreted in the faeces (Table 2) were calculated on the assumption that all ${ }^{15} \mathrm{~N}-\mathrm{NAN}$ in digesta and faeces was of rumen microbial origin. Although most ${ }^{15} \mathrm{~N}-\mathrm{NAN}$ flowing at the ileum was probably undigested residues of rumen microbes, small amounts of labelled endogenous secretions may also have been present. If so, rumen microbial NAN flow at the ileum is likely to be slightly overestimated and consequently true digestibility and absorption in the small intestine slightly underestimated. The digestibility of rumen microbial NAN in the small intestine did not differ between diets and the overall mean value was 0.72 whilst, in other 
studies, values of 0.71 for ${ }^{35} \mathrm{~S}$-labelled bacteria in the intestines of sheep (Bird, 1972), 0.75 and 0.85 for ${ }^{15} \mathrm{~N}$ - and ${ }^{35} \mathrm{~S}$-labelled bacteria respectively in young cattle (Salter \& Smith, 1978) and 0.82 in sheep (Storm et al. 1983) have been obtained.

\section{$N$ digestion in the large intestine}

With both diets a similar proportion $(0.63)$ of the ${ }^{15}$ N-NAN entering the large intestine was removed during passage of digesta to the anus. These results indicate that the absorption coefficient of rumen microbial residues in the large intestine was greater than that reported by Judson et al. (1975) for ${ }^{35} \mathrm{~S}$-labelled whole bacteria $(0 \cdot 42)$, when administered into the caecum. Nevertheless, it is possible that the values obtained in the present study may underestimate true absorption, since some of the faecal ${ }^{15} \mathrm{~N}$ could consist of ${ }^{15} \mathrm{~N}$ incorporated by microbes in the large intestine. Thus, it would appear that undigested rumen microbial $\mathbf{N}$ contributed very little to total faecal $\mathbf{N}$ which must have consisted largely of undigested dietary or endogenous NAN, or microbial N synthesized in the large intestine. The net loss of total $\mathrm{N}$ in the large intestine amounted to approximately $2 \mathrm{~g} / \mathrm{d}$ for each diet, and this was probably absorbed in the form of ammonia (Nolan et al. 1976; Dixon \& Nolan, 1982).

\section{$N$ metabolism in the body}

Because adult wethers, fed at maintenance, were used, net $\mathbf{N}$ deposition in the tissues would be expected to be limited to that occurring in wool growth, i.e. approximately $1.0 \mathrm{~g} / \mathrm{d}$ (Agricultural Research Council, 1980). Net $\mathrm{N}$ retention was in fact slightly higher than this when silage was consumed $(1.6 \mathrm{~g} / \mathrm{d})$ but lower when dried grass was consumed $(0.2 \mathrm{~g} / \mathrm{d})$ although the difference between diets was not significant $(P>0.05)$. As expected the higher digestible $\mathrm{N}$ intake with the silage was associated with a higher plasma urea concentration, urea synthesis rate and urinary urea excretion. The amount of non-urea $\mathrm{N}$ excreted in the urine was similar on the silage $(2.9 \mathrm{~g} / \mathrm{d})$ and dried grass $(3.3 \mathrm{~g} / \mathrm{d})$ and consequently urea accounted for a greater proportion of urinary $\mathrm{N}$ excretion when silage was consumed $(0 \cdot 78)$ than when dried grass was consumed $(0.51)$. Urea transfer to the whole digestive tract and to the post-ruminal part of the tract did not differ $(P>0.05)$ between diets whereas urea transfer to the rumen was higher when dried grass was consumed. Possible reasons for this have already been discussed.

\section{Whole-animal model of $N$ kinetics}

The results obtained were used to develop a schematic representation of the $\mathbf{N}$ transactions occurring both within and between the digestive tract and the tissues (Fig. 2). Not all pathways are included and a number of assumptions have been made. For example, urea recycled to the post-ruminal part of the digestive tract has been apportioned to the omasum and abomasum, the small intestine, and the large intestine, with the majority entering the small intestine since other studies (Dixon \& Nolan, 1983; Dixon \& Milligan, 1984) have shown that very little enters the large intestine. Despite its limitations the model summarizes the results of the present study and shows how results from digesta flow measurements and $\mathrm{N}$ kinetic studies may be combined to provide a better understanding of $\mathrm{N}$ metabolism in the whole animal.

One of the authors (J.V.N.) received financial support from the Agricultural and Food Research Council's Underwood Fund. Drs D. F. Osbourn and D. J. Thomson provided considerable helpful discussion and encouragement. The authors also wish to thank $\mathrm{Mr}$ S. B. Cammell and his staff for care of animals, and Mrs A. S. Keene (The Grassland Research Institute), Mr C. S. Lamb (The Hill Farming Research Organisation) and $\mathrm{Mr}$ 


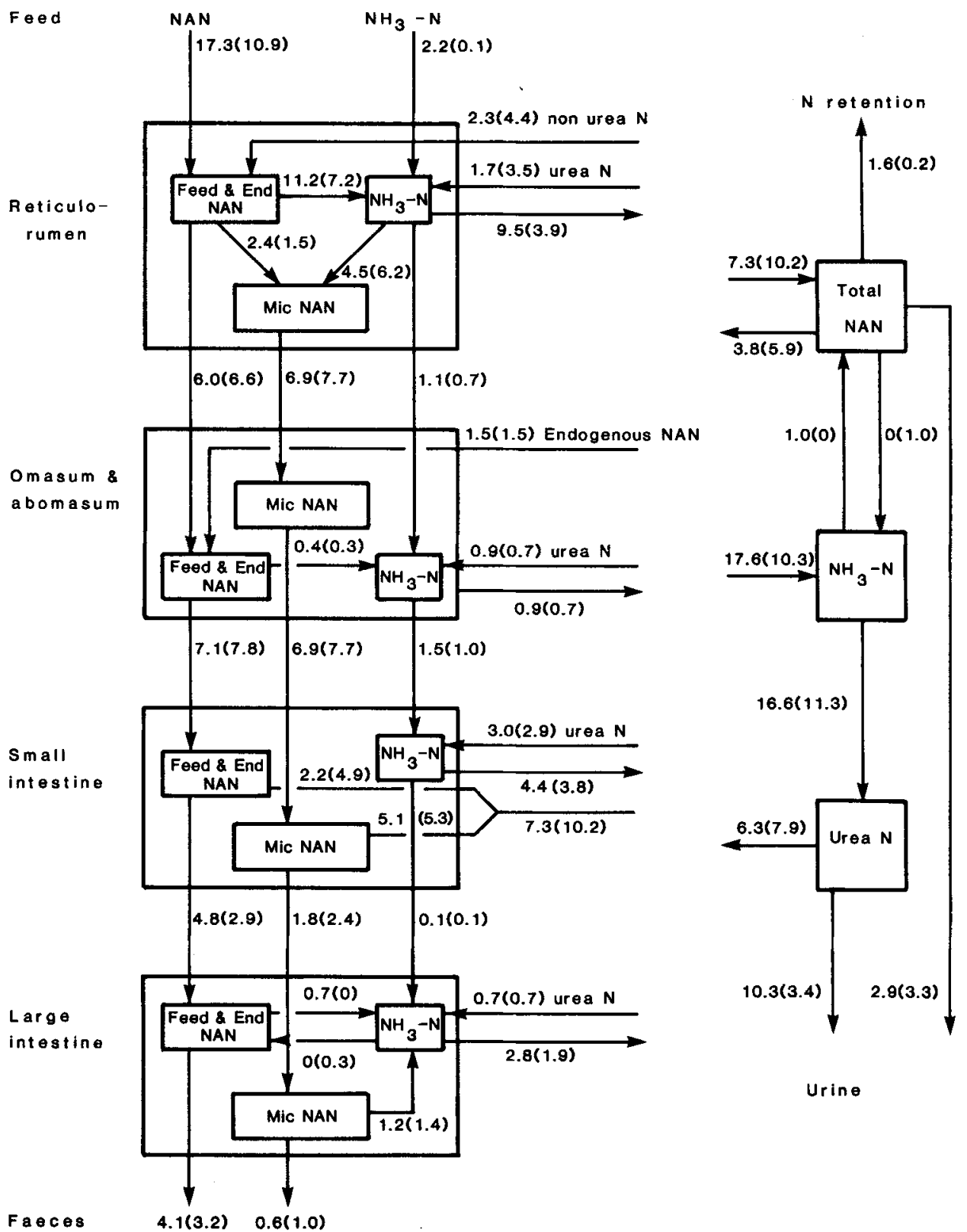

Fig. 2. Nitrogen transactions $(\mathrm{g} \mathrm{N} / \mathrm{d})$ in the gastrointestinal tract and tissues of sheep given a diet of grass silage. Corresponding values when dried grass was given are in parentheses. End NAN, endogenous non-ammonia-N; Mic NAN, microbial non-ammonia-N synthesized in the rumen.

S. J. Stachiw (University of New England) who gave major assistance with sample preparation and chemical analyses.

The Grassland Research Institute is financed through the Agricultural and Food Research Council and the work formed part of a commission from the Ministry of Agriculture, Fisheries and Food. 


\section{REFERENCES}

Agricultural Research Council (1980). The Nutrient Requirements of Ruminant Livestock. Farnham Royal: Commonwealth Agricultural Bureaux.

Beever, D. E. (1980). Occasional Symposium 11, British Grassland Society, pp. 131-143.

Beever, D. E., Kellaway, R. C., Thomson, D. J., MacRae, J. C., Evans, C. C. \& Wallace, A. S. (1978). Journal of Agricultural Science, Cambridge 90, 157-163.

Bird, P. R. (1972). Australian Journal of Biological Sciences 25, 195-203.

Dixon, R. M. \& Milligan, L. P. (1984). Canadian Journal of Animal Science 64, 103-111.

Dixon, R. M. \& Nolan, J. V. (1982). British Journal of Nutrition 47, 289-300.

Dixon, R. M. \& Nolan, J. V. (1983). British Journal of Nutrition 50, 757-768.

Engelhardt, V. W. \& Hauffe, R. (1975). In Digestion and Metabolism in the Ruminant, pp. 216-230. [1. W. McDonald and A. C. I. Warner, editors]. Armidale, Australia: University of New England Publishing Unit.

Faichney, G. J. (1975). In Digestion and Metabolism in the Ruminant, pp. 277-291 [I. W. McDonald and A. C. I. Warner, editors]. Armidale, Australia: University of New England Publishing Unit.

Harrop, C. J. F. (1974). Journal of Agricultural Science, Cambridge 83, 249-257.

Hogan, J. P. (1961). Australian Journal of Biological Science 14, 448-460.

Hogan, J. P. \& Weston, R. H. (1970). In Physiology of Digestion and Metabolism in the Ruminant, pp. 474-485 [A. T. Phillipson, editor]. Newcastle upon Tyne: Oriel Press.

Hungate, R. E. (1966). The Rumen and its Microbes. New York: Academic Press.

Judson, G. J., Abdelsamie, R. \& Bird, R. B. (1975). Australian Journal of Agricultural Research 26, $743-749$.

Kempton, T. J., Nolan, J. V. \& Leng, R. A. (1979). British Journal of Nutrition 42, 303-315.

Kennedy, P. M. \& Milligan, L. P. (1980). Canadian Journal of Animal Science 60, 205-221.

Lewis, D., Hill, K. J. \& Annison, E. F. (1957). Biochemical Journal 66, 587-592.

MacRae, J. C. (1975). In Digestion and Metabolism in the Ruminant, pp. 261-276 [I. W. McDonald and A. C. I. Warner, editors]. Armidale, Australia: University of New England Publishing Unit.

Nolan, J. V. (1975). In Digestion and Metabolism in the Ruminant, pp. 416-43] [1. W. McDonald and A. C. I. Warner, editors]. Armidale, Australia: University of New England Publishing Unit.

Nolan, J. V. \& Leng, R. A. (1972). British Journal of Nutrition 27, 177-194.

Nolan, J. V. \& Leng, R. A. (1974). Proceedings of the Nutrition Society 33, 1-8.

Nolan, J. V., Norton, B. W. \& Leng, R. A. (1976). British Journal of Nutrition 35, 127-147.

Nolan, J. V. \& Stachiw, S. (1979). British Journal of Nutrition 42, 63-80.

Norton, B. W., Janes, A. N. \& Armstrong, D. G. (1982). British Journal of Nutrition 48, $265-274$.

Salter, D. N. \& Smith, R. H. (1977). British Journal of Nutrition 38, 207-216.

Satter, L. D. \& Slyter, L. L. (1974). British Journal of Nutrition 32, 199-208.

Siddons, R. C., Beever, D. E. \& Kaiser, A. G. (1982 a). Journal of the Science of Food and Agriculture 33, 609-613. Siddons, R. C., Beever, D. E. \& Nolan, J. V. (1982b). British Journal of Nutrition 48, 377-389.

Snedecor, G. W. \& Cochran, W. G. (1967). Statistical Methods, 6th ed. Ames, Iowa: Iowa State University Press. Storm, E., Brown, D. S. \& Ørskov, E. R. (1983). British Journal of Nutrition 50, 479-485.

Thomas, P. C., Chamberlain, D. G., Kelly, N. C. \& Wait, M. K. (1980). British Journal of Nutrition 43, $469-479$. Visek, W. J. (1968). Journal of Dairy Science 51, 286-295.

Warner, A. C. I. \& Stacy, D. B. (1968). British Journal of Nutrition 22, 369-387. 